\title{
Developing Knowledge, Attitude, Motivation, and Behavior of Farmers in Diversification of Farming Business Sustainable in Technical Irrigation in South Sulawesi
}

\author{
Faizal Amir ${ }^{1}$, Muhammad Ardi ${ }^{2}$, Bakhrani Abdul Rauf ${ }^{2}$, Haruna Haji Latang ${ }^{1}$, Yasdin ${ }^{1}$, \\ Mithen Lullulangi ${ }^{2}$ \\ ${ }^{1}$ Department of Automotive Engineering Education, Universities Negeri Makassar, Makassar, Indonesia \\ ${ }^{2}$ Department of Civil Engineering and Planning Education, Universities Negeri Makassar, Makassar, Indonesia
}

Email address:

Faizalamir64@unm.ac.id (F. Amir), m.ardi@um.ac.id (M. Ardi), bakhrani@unm.ac.id (B. A. Rauf), haruna@unm.ac.id (H. H. Latang), yasdin@unm.ac.id (Yasdin), mithen@unm.ac.id (M. Lullulangi)

\section{To cite this article:}

Faizal Amir, Muhammad Ardi, Bakhrani Abdul Rauf, Haruna Haji Latang, Yasdin, Mithen Lullulangi. Developing Knowledge, Attitude, Motivation, and Behavior of Farmers in Diversification of Farming Business Sustainable in Technical Irrigation in South Sulawesi. American Journal of Environmental Science and Engineering. Vol. 5, No. 3, 2021, pp. 70-75. doi: 10.11648/j.ajese.20210503.13

Received: August 16, 2021; Accepted: August 26, 2021; Published: August 31, 2021

\begin{abstract}
Technical irrigation is a very large state investment, to support the economy, especially in agrarian countries, namely to irrigate rice-producing fields as a source of staple food for the community, especially in Indonesia. Irrigated areas need to be maintained so that they provide the greatest benefit to farmers and the community in a sustainable manner. Farmers need knowledge, attitudes, motivation, and behavior to diversify farming, so that agricultural land can be planted with various kinds of farming that are profitable for farmers. Therefore, farmers need to be trained on: farming diversification, ecosystems of irrigated agricultural areas, conservation, the environment, and farming. This study aims to: (1) determine the knowledge, attitudes, motivation, and behavior of farmers to diversify their farming business in a sustainable manner in technical irrigation areas before and after experiments on ecosystems, environment, conservation, and farming; (2) determine the effect of experimentation on increasing knowledge, attitudes, motivation, and behavior of farmers to diversify farming in a sustainable manner in technical irrigation areas. This research is classified as an experimental research conducted in the technical irrigation area of South Sulawesi. The sample area is Rompegading Village as the experimental area, and Pattojo Village as the control area, selected by purposive sampling method. The samples of the experimental group and the control group were 25 farmers each, also selected by the purposive sampling method. The variables to be considered are: (1) knowledge, attitude, motivation, and behavior of farmers to diversify their farming business before and after being given an experiment; (2) the effect of experimentation on increasing knowledge, attitudes, motivation, and behavior of farmers to diversify their farming business., The experimental design used was the pretest-posttest control group design. The data analysis used is descriptive statistical analysis and inferential statistical analysis. The inferential analysis model used is independent $t$ test. The results showed that: (1) knowledge, attitudes, motivation, and behavior of farmers to diversify their farming business, in the experimental group and the control group before the experiment, were in the low category. After the experiment the experimental group increased and was in the high category, while the control group did not experience an increase; (2) experiments have a significant effect on increasing knowledge, attitudes, motivation, and behavior of farmers to diversify farming in a sustainable manner in technical irrigation areas.
\end{abstract}

Keywords: Farmers, Diversification, Farming, Technical Irrigation Area, Experiment

\section{Introduction}

Technical irrigation area is a state investment that has a very large value and is a built environment for farmers. This irrigation area needs to be maintained so that it provides the greatest benefit to farmers and other communities in a sustainable manner. Farmers need knowledge, attitudes, motivation, and behavior to diversify farming, so that agricultural land can be planted with various kinds of farming that are profitable for farmers. Therefore, farmers need to be 
trained on: farming diversification, ecosystems of irrigated agricultural areas, conservation, the environment, and farming. The research objectives are as follows: (1) knowing the knowledge, attitude, motivation, and behavior of farmers to diversify their farming business in technical irrigation areas before and after the experiment regarding: diversification of farming business, ecosystem of irrigated agricultural areas, conservation, environment, and farming, (2) knowing the effect of experiments whose materials are: how to avoid the corona virus, ecosystems in wet agricultural areas, conservation, the environment, and farming on increasing knowledge, attitudes, motivation, and behavior of farmers to avoid the corona virus in diversifying their farming business technical irrigation area.

The theory underlying this research is described as follows. It basically states that the development of a training model through its activity cycle starts from: conducting a training needs analysis; designing training approaches; development of training materials; implementation of training; evaluation and improvement of training [1]. It designs a training model that starts from: identifying goals, formulating tests, developing learning strategies, and conducting evaluations [2].

The environment is a system which is a unitary space with all objects, power, circumstances, and living things including humans and their behavior that determines the life and welfare of humans and other living creatures [3]. The essence of environmental management by humans is how humans make efforts so that human quality is increasing, while the quality of the environment is also getting better [4].

The purpose of irrigation development is to meet the water needs for agricultural purposes, for soil processing, fertilization, soil temperature control, controlling pests [5]. Irrigation in rice fields can be divided into: (1) rural irrigation, and (2) government irrigation [6]. The principles of technical irrigation networks are as follows: (1) obtaining a separate water supply from the drainage network, (2) the supply of water can be measured and regulated, (3) tertiary plots occupy a central function, (4) all irrigation buildings are permanent [7].

Knowledge is all that we know about a particular object [8]. The better knowledge will have an impact on increasing attitudes, motivation, and behavior [4]. Knowledge consists of three components, namely cognitive, affective, and psychomotor [8]. Attitude is a person's evaluative response to the environment. Attitude consists of three components, namely affection, cognition, and conation [9]. Attitude is an evaluation or human response to environmental stimuli [10]. Attitudes are formed by a person's knowledge, experience, and sensing of the attitude object [9].

Motivation is a person's encouragement to carry out activities [11]. This motivation consists of two parts, namely motivation that comes from within humans (intrinsic) and motivation that comes from outside humans (extrinsic). Motivation arises because of a human need or desire that wants to be fulfilled [4].

Behavior is a series of actions built by knowledge, filing, values and attitudes [4]. Behavior is an individual action or reflection caused by psychological aspects, such as knowledge, perceptions, intentions, desires and attitudes [12]. Behavior is the result of a person's actions that are carried out continuously and have a tendency to be carried out continuously in the situations and conditions encountered [13].

Agricultural diversification is a process to transform the agricultural sector as a complex and broad effort to improve the agricultural economy through commodity diversification efforts [14]. The diversification program for farming, especially for paddy fields, has been launched by the government since Pelita I (1974-1978) which aims to increase farmers' income, expand employment opportunities, and reduce poverty [15].

\section{Material and Methods}

This type of research is experimental research conducted in technical irrigation areas. The experimental design used is the pretest-posttest control group design [16]. The experimental location is the Langkemme irrigation area, Soppeng Regency, selected by purposive sampling method. The experimental area is Rompegading Village and the control area is Pattojo Village. The experimental sample and control sample, each of 25 farmers, were selected by purposive sampling method. The variables to be considered are: (1) knowledge, attitude, motivation, and behavior of farmers to diversify their farming business in technical irrigation areas before and after being given training; (2) the effect of the experiment on increasing the knowledge, attitudes, motivation, and behavior of farmers to diversify their farming business in technical irrigation areas. Knowledge data were collected by giving tests, attitude data were collected by giving questionnaires, motivational data were collected by giving questionnaires, and farmer behavior data were collected by observing the samples before and after the experiment. The data analyses used were: (1) descriptive statistical analysis, (2) inferential statistical analysis, the analysis model used was independent $t$ test.

\section{Results}

\subsection{Description of the Knowledge of Farmers in the Experimental Group and the Control Group}

The results of the descriptive statistical analysis of 20 True-False questions about the knowledge of the experimental group farmers to diversify their farming business in technical irrigation areas before the implementation of the experiment showed that the average value $=5.84$; maximum $=10$; and minimum $=3$. The average value is in the low category. After the experiment, the mean value $=13.54$; maximum $=17$; and minimum $=8$. Thus, it can be concluded that the knowledge of the experimental group farmers before the experiment was in the low category, after the experiment increased and was in the high category. 
The results of the descriptive statistical analysis of 20 True-False questions about the knowledge of the control group farmers diversifying their farming business in technical irrigation areas before the experiment was carried out showed that the average value $=5.67$; maximum $=9$; and minimum $=3$. The average value is in the low category. After the experiment, the mean value $=5.68$; maximum $=10$; and minimum $=3$. Thus, it can be concluded that the knowledge of the control group farmers before and after the experiment remained in the low category.

\subsection{Description of the Attitude of Farmers in the Experimental Group and the Control Group}

The results of descriptive statistical analysis of 20 attitude statements adopted from the Likert scale, about the attitude of the experimental group farmers to diversify their farming business in technical irrigation areas before the experiment showed that the average value $=46.72$; maximum $=64$; and minimum $=24$. The average value is in the negative category. After the experiment, the average value $=75.68$; maximum $=86$; and minimum $=40$. The average value is in the positive category. Thus, it can be concluded that the attitude of the experimental group farmers before the experiment was in the negative category, after the experiment increased to positive.

The results of descriptive statistical analysis of 20 attitude statements adopted from the Likert scale, about the attitude of the control group farmers to diversify their farming business in technical irrigation areas before the implementation of the experiment showed that the average value $=44.78$; maximum $=62$; and minimum $=27$. The average value is in the negative category. The attitude of farmers after the experiment showed that the average value $=46.14$; maximum $=64$; and minimum $=26$. The average value is in the negative category. Thus, it can be concluded that the attitude of the control group farmers before and after the experiment remained in the negative category.

\subsection{Description of the Motivation of Farmers in the Experimental Group and the Control Group}

The results of descriptive statistical analysis of 20 motivational statements adopted from the Likert scale, about the motivation of the experimental group farmers to diversify their farming business in technical irrigation areas prior to the experiment showed that the average value $=47.24$; maximum $=63$; and minimum $=32$. The average value is in the low category. After the experiment it showed that the average value $=72.34$; maximum $=88$; and minimum $=55$. The average value is in the high category. Thus, it can be concluded that the motivation of the experimental group farmers before the experiment was in the low category, and after the experiment increased to high.

The results of the descriptive statistical analysis of 20 motivational statements adopted from the Likert scale, about the motivation of the control group farmers to diversify their farming business in technical irrigation areas before the implementation of the experiment showed that the average value $=45.74$; maximum $=64$; and minimum $=28$. The average value is in the low category. After the experiment it showed that the average value $=46.32$; $\operatorname{maximum}=63$; and minimum $=28$. The average value is in the low category. Thus, it can be concluded that the motivation of the control group farmers before and after the experiment remained in the low category.

\subsection{Description of the Behavior of Farmers in the Experimental Group and the Control Group}

The results of the descriptive statistical analysis of 20 observations of the behavior of the experimental group farmers in diversifying their farming business in technical irrigation areas before the experiment was carried out showed that the average value $=45.64$; $\operatorname{maximum}=66$; and minimum $=29$. The average value is in the low category. After the experiment it showed that the average value=78.46; maximum $=87$; and minimum $=57$. The average value is in the high category. Thus, it can be concluded that the behavior of the experimental group farmers before the experiment was in the low category, after the experiment increased to high.

The results of the descriptive statistical analysis of 20 observations of the behavior of the control group farmers diversifying their farming business in technical irrigation areas before the experiment was carried out showed that the average value $=46.24$; maximum $=63$; and minimum $=30$. The average value is in the low category. After the experiment it showed that the average value $=46.32$; maximum $=64$; and minimum $=31$. The average value is in the low category. Thus, it can be concluded that the behavior of the control group farmers before and after the experiment was in the low category.

\subsection{The Effect of Experiments on Increasing Knowledge of Farmers to Diversify Farming in Technical Irrigation Areas}

The results of the analysis of the effect of the experiment on increasing the knowledge of farmers to diversify their farming business in technical irrigation areas are shown in Table 1.

Table 1. The results of the analysis of the effect of the experiment on increasing the knowledge of farmers to diversify their farming business in technical irrigation areas.

\begin{tabular}{|c|c|c|c|c|c|c|c|c|}
\hline & \multicolumn{5}{|c|}{ Paired differences } & \multirow{3}{*}{$t$} & \multirow{3}{*}{$d f$} & \multirow{3}{*}{ Sig. (2-tailed) } \\
\hline & \multirow{2}{*}{ Mean } & \multirow{2}{*}{ Std. deviation } & \multirow{2}{*}{$\begin{array}{l}\text { Std. error } \\
\text { mean }\end{array}$} & \multicolumn{2}{|c|}{$95 \%$ confidence interval of the difference } & & & \\
\hline & & & & Lower & Upper & & & \\
\hline $\begin{array}{l}R=0.94 \\
R^{2}=0.88\end{array}$ & 7.42 & 1.33 & 0.32 & 8.92 & 5.93 & 21.93 & 24 & 0.000 \\
\hline
\end{tabular}


Based on the results of the analysis in Table 1, it looks significant $t=0.000<\alpha=0.05$. This means that the experiment has a significant effect on increasing the knowledge of farmers to diversify their farming business in technical irrigation areas The coefficient of determination $R^{2}=0.88$. This figure shows that the effect of the experiment on increasing the knowledge of farmers to diversify their farming business in technical irrigation areas is $88 \%$.

\subsection{The Effect of the Experiment on Improving the Attitude of Farmers}

The results of the analysis of the effect of the experiment on increasing the attitude of farmers to diversify their farming business in technical irrigation areas are shown in Table 2.

Table 2. The results of the analysis of the effect of the experiment on increasing the attitude of farmers to diversify their farming business in technical irrigation areas.

\begin{tabular}{|c|c|c|c|c|c|c|c|c|}
\hline & \multicolumn{5}{|c|}{ Paired differences } & \multirow{3}{*}{$t$} & \multirow{3}{*}{$d f$} & \multirow{3}{*}{ Sig. (2-tailed) } \\
\hline & \multirow{2}{*}{ Mean } & \multirow{2}{*}{ Std. devia tion } & \multirow{2}{*}{$\begin{array}{l}\text { Std. error } \\
\text { mean }\end{array}$} & \multicolumn{2}{|c|}{$95 \%$ confidence interval of the difference } & & & \\
\hline & & & & Lower & Upper & & & \\
\hline $\begin{array}{l}R=0.968 \\
R^{2}=0.937\end{array}$ & 21.7 & 2.1 & 1.52 & 25.64 & 17.76 & 19.73 & 24 & 0.000 \\
\hline
\end{tabular}

Based on the results of the analysis in Table 2 , it is seen that $t=0.000<\alpha=0.05$ is significant. This means that the experiment has a significant effect on increasing the attitude of farmers to diversify their farming business in technical irrigation areas. The coefficient of determination $R^{2}=0.937$. This figure shows that the effect of the experiment on increasing the attitude of farmers to diversify their farming business in technical irrigation areas is $93.7 \%$.

\subsection{The Effect of the Experiment on Increasing the Motivation of Farmers}

The results of the analysis of the effect of the experiment on increasing the motivation of farmers to diversify their farming business in technical irrigation areas are shown in Table 3.

Table 3. The results of the analysis of the effect of the experiment on increasing the motivation of farmers to diversify their farming business in technical irrigation areas.

\begin{tabular}{|c|c|c|c|c|c|c|c|c|}
\hline & \multicolumn{5}{|c|}{ Paired differences } & \multirow{3}{*}{$t$} & \multirow{3}{*}{$d f$} & \multirow{3}{*}{ Sig. (2-tailed) } \\
\hline & \multirow{2}{*}{ Mean } & \multirow{2}{*}{ Std. devia tion } & \multirow{2}{*}{$\begin{array}{l}\text { Std. error } \\
\text { mean }\end{array}$} & \multicolumn{2}{|c|}{$95 \%$ confidence interval of the difference } & & & \\
\hline & & & & Lower & Upper & & & \\
\hline $\begin{array}{l}R=0.901 \\
R^{2}=0.81\end{array}$ & 18.65 & 0.69 & 0.97 & 23.53 & 13.78 & 20.47 & 24 & 0.000 \\
\hline
\end{tabular}

Based on the results of the analysis in Table 3, it is seen that $t=0.000<\alpha=0.05$ is significant. This means that the experiment has a significant effect on increasing the motivation of farmers to diversify their farming business in technical irrigation areas. The coefficient of determination $R^{2}=0.81$. This figure shows that the effect of the experiment on increasing the motivation of farmers to diversify their farming business in technical irrigation areas is $81 \%$.

\subsection{The Effect of Experiments on Improving the Behavior of Farmers}

The results of the analysis of the effect of experiments on improving the behavior of farmers to diversify their farming business in technical irrigation areas are shown in Table 4.

Table 4. The results of the analysis of the effect of experiments on improving the behavior of farmers to diversify their farming business in technical irrigation areas.

\begin{tabular}{|c|c|c|c|c|c|c|c|c|}
\hline & \multicolumn{5}{|c|}{ Paired differences } & \multirow{3}{*}{$t$} & \multirow{3}{*}{$d f$} & \multirow{3}{*}{ Sig. (2-tailed) } \\
\hline & \multirow{2}{*}{ Mean } & \multirow{2}{*}{ Std. devia tion } & \multirow{2}{*}{$\begin{array}{l}\text { Std. error } \\
\text { mean }\end{array}$} & \multicolumn{2}{|c|}{$95 \%$ confidence interval of the difference } & & & \\
\hline & & & & Lower & Upper & & & \\
\hline $\begin{array}{l}R=0.926 \\
R^{2}=0.857\end{array}$ & 20.31 & 2.33 & 1.56 & 25.27 & 15.36 & 21.35 & 24 & 0.000 \\
\hline
\end{tabular}

Based on the results of the analysis in Table 4 , it is seen that $t=0.000<\alpha=0.05$ is significant. This means that the experiment has a significant effect on improving the behavior of farmers to diversify their farming business in technical irrigation areas. The coefficient of determination $R^{2}=0.857$. This figure shows that the effect of the experiment on improving the behavior of farmers to diversify their farming business in technical irrigation areas is $85.7 \%$.

\section{Discussion}

The knowledge of farmers in the experimental group and the control group before being given an experiment was in the low category. After being given the experiment, the knowledge of the experimental group farmers increased to high, while the knowledge of the control group farmers 
remained low. There was a very significant difference in the knowledge of the experimental group farmers with the control group. The experimental group was much better. This was caused by: (1) the presenter provided good material, (2) the method used was in accordance with the conditions of the farmers, and (3) the experiment was carried out to control the testing effect, maturation effect, and mortality effect. The effect of the experiment is very significant on increasing the knowledge of farmers to diversify their farming business in technical irrigation areas.

The attitude of the farmers in the experimental group and the control group before being given the experiment was in the negative category. After being given the experiment, the attitude of the experimental group farmers increased to positive, while the attitude of the control group farmers remained negative. There is a very significant difference in the attitude of farmers in the experimental group with the control group. The experimental group was much better. This is due to (1) the presenters provide good material, (2) the method used is in accordance with the conditions of the farmers, and (3) experiments were carried out to control the effect of testing, the effect of ripening, and mortality. affect. The effect of the experiment is very significant on increasing the attitude of farmers to diversify their farming in technical irrigation areas.

The motivation of farmers in the experimental group and the control group before being given an experiment was in the low category. After being given the experiment, the motivation of the experimental group farmers increased to high, while the motivation of the control group farmers remained low. There was a very significant difference in the motivation of the experimental group farmers with the control group. The experimental group was much better. This was caused by: (1) the presenter provided good material, (2) the method used was in accordance with the conditions of the farmers, and (3) the experiment was carried out to control the testing effect, maturation effect, and mortality effect. The effect of the experiment is very significant on increasing the motivation of farmers to diversify their farming business in technical irrigation areas.

The behavior of farmers in the experimental group and the control group before being given an experiment was in the low category. After being given the experiment, the behavior of the experimental group farmers increased to high, while the behavior of the control group farmers remained low. There was a very significant difference in the behavior of the experimental group farmers with the control group. The experimental group was much better. This was caused by: (1) the presenter provided good material, (2) the method used was in accordance with the conditions of the farmers, and (3) the experiment was carried out to control the testing effect, maturation effect, and mortality effect. The effect of the experiment is very significant on increasing the behavior of farmers to diversify their farming business in technical irrigation areas.

The results of this study are in line with the results of research conducted by Mardin et al, that the level of knowledge and motivation of farmers in farming is in the low category [17]. So in this study, conducting experiments in the form of treatment of farmers, so that the knowledge and motivation of farmers can increase. In addition, the factors that have a significant influence on the behavior of farmers to do farming are the motivation to achieve success, insight into land conservation, the activity of farmers seeking land conservation information, and the intensity of extension workers [18]. This also supports the results of this study, that treatment plays a very important role in increasing the knowledge and motivation of farmers in farming.

\section{Conclusions}

Based on the results of research and discussion, as well as the objectives of this study, conclusions can be drawn as follows: (1) knowledge, attitude, motivation, and behavior of farmers to diversify farming in technical irrigation areas, both the experimental group and the control group before the experiment were in the low category. The knowledge, attitudes, motivation, and behavior of the experimental group farmers after the experiment were in the high category, while the control group remained in the low category; (2) experiments have a very significant effect on increasing the knowledge, attitudes, motivation, and behavior of farmers to diversify their farming business in technical irrigation areas.

\section{Acknowledgements}

Acknowledgments are conveyed to: (1) Ministry of Research and Technology/National Research and Innovation Agency and Higher Education who have funded this research as a form of guidance for lecturers in Higher Education; (2) The Chancellor of Makassar State University for his permission, guidance, and motivation so that this research can be carried out properly; (3) Chairman of the Institute for Research and Community Service (LP2M) Makassar State University, for his support and direction so that this research can be carried out properly; (4) Soppeng District Government for their support and granting of permits to conduct research; (5) Farmers as research respondents for their participation and cooperation; (6) All members of the research team for their good cooperation; and (7) All parties who have participated in this research, not mentioned one by one. Hopefully what has been done by all parties and teams in completing this research can provide the maximum benefit for Makassar State University, the Community, the Nation and the State.

\section{References}

[1] Hanrahmawan, F. 2010. "Revitalisasi Manajemen Pelatihan Tenaga Kerja (Studi Kasus pada Balai Latihan Kerja Industri Makassar)." Jurnal Administrasi Publik. 1 (1): 78-94 (in Indonesian).

[2] Sanjaya, W. 2011. Strategi Pembelajaran Berorientasi Standar Proses Pendidikan. Jakarta: Kencana Prenada Media (in Indonesian). 
[3] Undang-Undang Republik Indonesia Nomor 32 tahun 2009 tentang Perlin-dungan dan Pengelolaan Lingkungan Hidup (in Indonesian).

[4] Faizal, A., Muhamad, A., and dan Marsus, S. 2018. Pembinaan Petani Dalam Meningkatkan Pendapatan dan Kualitas lingkungan Secara Berkelanjutan di Daerah Irigasi Teksnis Sulawesi Selatan. Edisi II. Makassar: Badan Penerbit UNM (in Indonesian).

[5] Laycock, A. 2007. Irrigation System Design, Planning and Construction. Wallingford: CABI Head Office.

[6] Ansori, M. B., AND Edijanto, D. S. R. S. 2018. Irigasi dan Bangunan Air. Surabaya: Institut Teknologi Sepuluh Nopember (in Indonesian).

[7] Mawardi, E. 2010. Desain Hidraulik Bangunan Irigasi. Bandung: Penerbit Alfabeta (in Indonesian).

[8] Suriasumantri. 2010. Filsafat Ilmu: Sebuah Pengantar Populer. Jakarta: Pustaka Sinar Harapan (in Indonesian).

[9] Azwar, S. 2013. Sikap Manusia, Teori dan Pengukurannya. Yogyakarta: Penerbit Pustaka Pelajar (in Indonesian).

[10] Vivas, A., Gelaye, B., Aboset, N., Kumie, A., Berhane, Y., and Williams, M. A. 2010. "Knowledge, Attitudes, and Practices (KAP) of Hygiene among School Children in Angolela, Ethiopia." Journal of Preventive Medicine and Hygiene 51 (2): 73-9.

[11] Adnil, E. N. 2011. Tumbuh Kembang Perilaku Manusia. Jakarta: Penerbit Buku Kedokteran EGC (in Indonesian).
[12] Jiang, G., Boulton, M. L., Wang, Z., Li, J., Li, W., Wang, D. Z., Liu, H., Zheng, W. L., Yang, Y., Chang, G., Zhang, F., and Montgomery, J. P. 2012. "Community Intervention Trial Promote Healty Behaviors in Farmers in Tianjin, China." Journal of Behavioral Health 1 (2): 77-85.

[13] Tukiyat. 2009. "Perilaku Masyarakat Situ Rawa Besar dalam Mengelola Lingkungan.” In Disertasi. Jakarta: Program Pascasarjana Universitas Negeri Jakarta (in Indonesian).

[14] Bunasor, S. 2011. Sumberdaya Air dan Kesejahteraan Publik (Suatu Tinjauan Teoritis dan Kajian Praktis). Bogor: IPB Press (in Indonesian).

[15] Damanhuri, Rr. M. M., and Dwi Putro, S. S. 2017. "Pengembangan diversifikasi usaha tani sebagai penguatan Ekonomi di kabupaten bojonegoro, tulungagung, dan Ponorogo.” Jurnal Cakrawala. 11 (1): 33-47 (in Indonesian).

[16] Borg \& Gall. 2007. Educational Research: An Introduction, 8th ed. New York: Pearson.

[17] Mardin, S dan Wasariana, (2017). Hubungan Tingkat Pengetahuan dengan Motivasi dalam Usahatani padi sawah di desa Tanjung Batu Kecamatan Kabawo Kabupaten Muna. Buletin Sosek, Edisi No. 35 Tahun 19. April 2017. ISSN: 1410-4466.

[18] Ratnada, M dan Yusuf. (2003). Perilaku Petani dalam Konservasi Lahan pada Sistem Usaha Pertanian Padi Sawah Irigasi di Imogiri, Bantul. Jurnal Pengkajian dan Pengembangan Teknologi Pertanian Vol. 6, No. 1, Januari 2003: 29-39. 